\title{
Pengaruh Independensi, Profesionalisme, Skeptisme Profesional, Etika Profesi dan Gender Terhadap Kualitas Audit Pada KAP di Bali
}

\author{
Ni Kadek Sri Rahayu ${ }^{1}$ \\ Fakultas Ekonomi dan Bisnis \\ Universitas Udayana, Indonesia \\ Email: kdrahayu16@yahoo.com
}

\author{
I Ketut Suryanawa ${ }^{2}$ \\ Fakultas Ekonomi dan Bisnis \\ Universitas Udayana, Indonesia
}

\begin{abstract}
ABSTRAK
Penelitian ini bertujuan untuk mengetahui pengaruh independensi profesionalisme etika profesi dan gender terhadap kualitas audit pada Kantor Akuntan Publik yang ada di Bali. Metode pengumpulan data dalam penelitian ini menggunakan kuesioner. Populasi dalam penelitian ini adalah seluruh auditor yang bekerja pada Kantor Akuntan Publik di Bali dengan jumlah auditor secara keseluruhan sebanyak 78 auditor. Teknik analisis yang digunakan adalah Regresi Linier Berganda. Berdasarkan analisis dan pengujian hipotesis, maka diperoleh kesimpulan bahwa (1) independensi berpengaruh positif terhadap kualitas audit, (2) profesionalisme berpengaruh positif terhadap kualitas audit, (3) skeptisme profesional berpengaruh positif terhadap kualitas audit, (4) etika profesi berpengaruh positif terhadap kualitas audit (5) gender berpengaruh negatif pada kualitas audit.
\end{abstract}

Kata Kunci : $\quad$ Independensi; Profesionalisme; Etika; Gender; Kualitas Audit.

\section{The Effect of Independence, Professionalism, Professional Skeptism, Professional Ethics and Gender on Audit Quality in KAP in Bali}

\begin{abstract}
This study aims to determine the effect of professionalism and gender professionalism independence on audit quality at public accounting firms in Bali. Data collection methods in this study used a questionnaire. The population in this study are all auditors who work at the Public Accounting Firm in Bali with a total of 78 auditors overall. The analysis technique used is Multiple Linear Regression. Based on the analysis and testing of hypotheses, the conclusion is that (1) independence has a positive effect on audit quality, (2) professionalism has a positive effect on audit quality, (3) professional skepticism has a positive effect on audit quality, (4) professional ethics has a positive effect on quality audit (5) gender negatively influences audit quality.
\end{abstract}

Keywords: $\quad$ Independence; Professionalism; Ethics; Gender; Audit Quality.

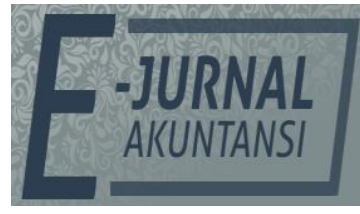

E-JA

e-Jurnal Akuntansi e-ISSN 2302-8556

Vol. 30 No. 3

Denpasar, Maret 2020

Hal. 686-698

Artikel Masuk:

4 Desember 2019

Tanggal Diterima: 28 Januari 2020 


\section{PENDAHULUAN}

Laporan keuangan adalah ringkasan dari proses pencatatan atas transaksitransaksi keuangan yang terjadi selama tahun berjalan. Laporan keuangan berdasarkan prinsip akuntansi yang diterima umum (Standar Akuntansi Keuangan), yang diterapkan secara konsisten dan tidak mengandung kesalahan yang material (besar atau immaterial) adalah laporan keuangan yang wajar. Manajemen dan semua pihak yang terlibat dalam kegiatan perusahaan serta pihak eksternal perusahaan meliputi kreditor, calon kreditor, investor, calon investor, kantor pajak, dan pihak-pihak lain yang tidak terlibat langsung dalam kegiatan perusahaan tetapi memiliki kepentingan dalam perusahaan agar mengetahui kemajuan perusahaan di masa datang memerlukan informasi keuangan untuk mengetahui keuangan perusahaan, pengambilan keputusan, dan memudahkan dalam mengelola perusaahaan. Menurut Financial Accounting Standards Board (FASB), dua karakteristik terpenting yang harus ada dalam laporan keuangan adalah relevan (relevance) dan dapat diandalkan (reliable). Kedua karakteristik tersebut sulit diukur, sehingga para pemakai informasi membutuhkan jasa akuntan publik. Jasa dari para akuntan yang bekerja di suatu Kantor Akuntan Publik (KAP) atau para auditor eksternal sangat dibutuhkan sebagai jaminan laporan keuangan tersebut memang relevan serta dapat meningkatkan kepercayaan pihak yang berkepentingan terhadap perusahaan tersebut. Akuntan Publik adalah profesi yang memberikan pelayanan bagi masyarakat umum, khususnya di bidang audit atas laporan keuangan yang disajikan oleh kliennya. Tugas akuntan publik adalah memeriksa laporan keuangan dan bertanggung jawab atas opini yang diberikan atas laporan keuangan sehingga bisa digunakan sebagai landasan dalam pengambilan keputusan.

Profesi akuntan publik merupakan profesi kepercayaan masyarakat. Guna menunjang profesionalismenya sebagai akuntan publik maka dalam melaksanakan tugas auditnya, auditor harus berpedoman pada standar audit yang ditetapkan oleh Institut Akuntan Publik Indonesia (IAPI), yakni standar umum, standar pekerjaan lapangan, dan standar pelaporan. Selain standar audit, seorang auditor juga harus mematuhi kode etik profesi yang mengatur tentang tanggung jawab profesi, kompetensi dan kehati-hatian profesional, kerahasiaan, perilaku profesional serta standar teknis bagi seorang auditor dalam menjalankan profesinya. Besarnya kepercayaan pengguna laporan keuangan pada Akuntan Publik ini mengharuskan akuntan publik memperhatikan kualitas auditnya. Namun, profesi auditor telah menjadi sorotan masyarakat dalam beberapa tahun terakhir. Mulai dari kasus Enron di Amerika Serikat, hingga kasus-kasus kecurangan pelaporan keuangan yang terjadi di dalam negeri, seperti kasus laporan keuangan ganda Bank Lippo, dan kasus mark-up laporan keuangan oleh manajemen PT. Kimia Farma Tbk yang membuat kredibilitas dan kualitas auditor semakin dipertanyakan, serta kasus-kasus lainnya. Kasus-kasus skandal akuntansi keuangan tersebut telah memberikan bukti bahwa pengabaian kualitas hasil kerja audit membawa akibat serius bagi masyarakat bisnis. Selain fenomena-fenomena skandal akuntansi keuangan tersebut, kualitas audit yang dihasilkan oleh akuntan publik juga tengah menjadi sorotan dari masyarakat umum, seperti kasus yang menimpa Akuntan Publik (AP) Justinus Aditya 
Sidharta pada tahun 2006 yang diindikasikan melakukan kesalahan dalam mengaudit laporan keuangan PT. Great River International, Tbk. Pada kasus tersebut AP Justinus Aditya Sidharta melakukan konspirasi dengan kliennya untuk menggelembungkan account penjualan, piutang, dan asset lainnya hingga ratusan milyar rupiah. Oleh karenanya Menteri Keuangan Republik Indonesia terhitung sejak tanggal 28 Nopember 2006 telah membekukan izin praktik bagi Akuntan Publik Justinus Aditya Sidaharta selama dua tahun karena telah melanggar Standar Profesional Akuntan Publik (SPAP). Fenomena ini hanya satu dari beberapa Akuntan Publik yang terbukti telah melanggar SPAP. Masih banyak lagi kasus pelanggaran pada akhir-akhir ini yang dilakukan oleh akuntan publik. Maka dari itu kualitas audit sangat penting karena dengan kualitas audit yang tinggi maka akan dihasilkan laporan keuangan yang dapat dipercaya sebagai dasar pengambilan keputusan.

Profesi akuntan publik merupakan profesi kepercayaan masyarakat. Guna menunjang profesionalismenya sebagai akuntan publik maka dalam melaksanakan tugas auditnya, auditor harus berpedoman pada standar audit yang ditetapkan oleh Institut Akuntan Publik Indonesia (IAPI), yakni standar umum, standar pekerjaan lapangan, dan standar pelaporan. Selain standar audit, seorang auditor juga harus mematuhi kode etik profesi yang mengatur tentang tanggung jawab profesi, kompetensi dan kehati-hatian profesional, kerahasiaan, perilaku profesional serta standar teknis bagi seorang auditor dalam menjalankan profesinya. Besarnya kepercayaan pengguna laporan keuangan pada Akuntan Publik ini mengharuskan akuntan publik memperhatikan kualitas auditnya.

Seorang auditor dituntut memiliki sikap profesionalisme. Profesionalisme adalah tanggung jawab untuk berperilaku yang lebih dari sekedar memenuhi undang-undang dan peraturan masyarakat (Herliansyah \& Ilyas, 2006). Seseorang dikatakan bersikap profesionalisme jika memenuhi tiga kriteria, yaitu ahli untuk melaksanakan tugas sesuai dengan bidangnya, melaksanakan tugas atau profesi dengan menerapkan standar baku di bidang profesi yang bersangkutan, dan yang terakhir mematuhi etika profesi yang telah ditetapkan (Herawaty \& Susanto, 2009).

Auditor dalam menjalankan tugas auditnya, tidak hanya dituntut patuh terhadap kode etik profesi, melainkan juga dituntut untuk menerapkan skeptisme profesionalnya. Paragraf ketujuh Standar Audit seksi 200 (IAPI, 2013) menjelaskan skeptisisme profesional adalah sikap yang mencakup pikiran yang selalu mempertanyakan dan melakukan evaluasi secara kritis terhadap bukti audit. Dengan skeptisisme profesional, auditor diharapkan dapat melaksanakan tugasnya sesuai dengan standar yang ditetapkan, menjunjung tinggi kaidah dan norma agar kualitas audit serta citra profesi auditor tetap terjaga.

Hal dasar yang harus diperhatikan oleh auditor adalah etika dalam berprofesi. Pelaksanaan pekerjaan profesional tidak lepas dari etika karena perilaku profesional diperlukan bagi semua profesi agar profesi yang dijalaninya mendapat kepercayaan dari masyarakat. Dengan kesadaran etis yang tinggi, maka seorang auditor cenderung profesional dalam tugasnya dan menjalankan tugasnya sesuai dengan kode etik profesi dan standar audit sehingga hasil audit yang dilakukan akan lebih menunjukkan keadaan yang sebenarnya. 
Gender juga bisa dikatakan faktor individu yang turut mempengaruhi kualitas audit. Gender tidak hanya sebagai pembeda antara laki-laki dan perempuan secara biologis tetapi gender lebih dilihat dari segi sosial dan cara mereka menerima, menghadapi dan memproses informasi yang diterima untuk melaksanakan pekerjaan dan membuat keputusan. Auditor laki-laki dan perempuan mempunyai sifat dan karakter yang berbeda-beda untuk masingmasing individu. Auditor perempuan diduga lebih efisien dan efektif dalam memproses informasi saat adanya kompleksitas tugas dalam pengambilan keputusan dibandingkan auditor laki-laki. Hal tersebut diduga karena auditor perempuan memiliki kemampuan untuk membedakan dan mengintegrasikan kunci keputusan dibandingkan auditor laki-laki yang mendalam dalam menganalisis inti dari suatu keputusan (Yustrianthe, 2012).

Penelitian mengenai hubungan independensi dengan kualitas audit telah banyak dilakukan, seperti penelitian Sugiarmini \& Datrina, (2017) menemukan hasil bahwa independensi berpengaruh signifikan terhadap kualitas audit, begitu juga penelitian Wardhani \& Astika, (2018) memiliki hasil penelitian yang sama yaitu independensi berpengaruh positif pada kualitas audit. Hasil penelitian serupa oleh Lesmana \& Machdar, (2015) juga menyatakan semakin tinggi tingkat independensi maka semakin berkualitas hasil auditnya. Berdasarkan uraian dan hasil penelitian sebelumnya maka maka hipotesis dalam penelitian ini adalah sebagai berikut.

$\mathrm{H}_{1}$ : Independensi berpengaruh positif pada kualitas audit.

Profesionalisme merupakan syarat utama bagi seorang auditor yang bekerja di kantor akuntan publik. Profesionalisme adalah keadaan dimana seorang auditor wajib melaksanakan tugas-tugasnya dengan kesungguhan dan kecermatan. Profesionalisme pada hakikatnya merupakan suatu sikap yang dimiliki oleh seseorang yang melaksanakan pekerjaan sesuai dengan keahlian dalam bidangnya masing-masing dan mampu meminimalisir kesalahan dalam melakukan pemeriksaan diharapkan dapat menghasilkan kualitas audit yang baik sesuai dengan standar audit yang telah ditetapkan. Penelitian yang dilakukan oleh Haryanto \& Susilawati, (2018) menemukan hasil bahwa profesionalisme berpengaruh positif terhadap kualitas audit, begitu juga dengan Lesmana \& Machdar, (2015) memiliki hasil penelitian yang sama yaitu profesionalisme berpengaruh terhadap kualitas audit. Sikap profesionalisme berpengaruh dalam memberikan perubahan yang berarti terhadap Kualitas Audit. Berdasarkan uraian dan hasil penelitian sebelumnya maka maka hipotesis dalam penelitian ini adalah sebagai berikut.

$\mathrm{H}_{2}$ : Profesionalisme berpengaruh positif terhadap Kualitas Audit

Menurut IAPI, (2013) penggunaan kemahiran profesional dengan cermat dan seksama menuntut auditor untuk melaksanakan skeptisme profesional. Skeptisme profesional adalah sikap yang mencakup pikiran yang selalu mempertanyakan dan melakukan evaluasi secara kritis terhadap bukti audit. Seorang auditor yang skeptis tidak akan menerima begitu saja penjelasan dari klien, tetapi akan mengajukan pertanyaan untuk memperoleh alasan, bukti dan konfirmasi mengenai objek yang dipermasalahkan (Waluyo, 2001).

Dalam skeptisme profesional, sikap auditor yang tidak mudah percaya dengan bukti yang kurang meyakinkan walaupun menurut anggapan 
manajemen adalah jujur (Rai, 2008). Carpenter, et al., (2002) menyatakan bahwa auditor yang kurang memiliki sikap skeptik akan menyebabkan penurunan kualitas audit.Penelitian yang dilakukan oleh Sugiarmini \& Datrina, (2017) menemukan hasil bahwa skeptisme profesional berpengaruh positif terhadap kualitas audit. Adrian, (2013) juga menemukan faktor yang berpengaruh positif terhadap kualitas audit adalah skeptisme profesional auditor. Berdasarkan uraian dan hasil penelitian sebelumnya maka hipotesis dalam penelitian ini adalah sebagai berikut.

$\mathrm{H}_{3}$ : Skeptisme profesional berpengaruh positif terhadap Kualitas Audit.

Etika dapat didefinisikan sebagai seperangkat prinsip-prinsip moral atau nilai-nilai (Elder, et al., 2011). Dalam hal etika, sebuah profesi harus memiliki komitmen moral yang tinggi yang dituangkan dalam bentuk aturan khusus. Aturan ini merupakan aturan main dalam menjalankan atau mengemban profesi tersebut, yang biasa disebut sebagai kode etik. Kode Etik IAPI menjadi standar umum perilaku atas perilaku yang ideal dan ketetapan peraturan yang spesifik yang mengatur perilaku auditor (Elder, et al., 2011). Teori disonansi kognitif dapat menjelaskan bahwa timbulnya ketidakkonsistenan pada diri auditor untuk mengikuti atau tidak mengikuti sebagian dari kode etik, serta perbedaan persepsi individu mengenai hal yang etis atau tidak etis dapat menimbulkan ketidakselarasan. Oleh karena itu, jika auditor dapat menjaga keselarasan dalam etika profesinya maka akan dapat melaksanakan auditnya dengan baik sesuai yang diharuskan dalam kode etik profesi. Penelitian yang dilakukan oleh Futri \& Juliarsa, (2014) menemukan hasil bahwa etika profesi berpengaruh positif terhadap kualitas audit. Arumsari \& Budiartha, (2016) juga menemukan bahwa etika profesi berpengaruh positif terhadap kualitas audit. Berdasarkan uraian dan hasil penelitian sebelumnya maka maka hipotesis dalam penelitian ini adalah sebagai berikut.

$\mathrm{H}_{4}$ : Etika profesi berpengaruh positif terhadap Kualitas Audit.

Gender memberikan perbedaan dalam tingkat pertimbangan moral. Pertimbangan moral yang dimaksud adalah langkah pengambilan keputusan dan informasi dalam mengaudit perusahaan klien. Pengambilan keputusan harus didukung oleh informasi yang memadai. Laki-laki dalam pengolahan informasi tersebut biasanya tidak menggunakan seluruh informasi yang tersedia sehingga keputusan yang diambil kurang komprehensif dan kualitas hasil kerjanya kurang baik. Sedangkan, perempuan mereka dalam mengolah informasi cenderung lebih teliti dengan menggunakan informasi yang lebih lengkap dan mengevaluasi kembali informasi tersebut dan tidak gampang menyerah (Darley \& Smith, 1995). Perempuan relatif lebih efisien dibandingkan laki-laki dalam mendapat akses informasi. Selain itu, kaum wanita juga memiliki daya ingat yang lebih tajam terhadap suatu informasi baru dibandingkan kaum pria dan demikian halnya kemampuan dalam mengolah informasi lebih hati-hati sehingga dalam membuat keputusan judgment lebih tepat dibandingkan kaum pria. Kualitas audit sangat penting karena dengan kualitas audit yang tinggi maka akan dihasilkan laporan keuangan yang dapat dipercaya sebagai dasar pengambilan keputusan. Hasil penelitian Indayani, et al., (2015) dan Maulana, (2019) menyatakan bahwa gender berpengaruh pada kualitas audit. Perbedaan gender antara laki-laki dan perempuan dengan perbedaan berbagai sifat dan 
karakter individu masing-masing berpengaruh terhadap judgement yang berhubungan dengan kualitas audit yang diambil oleh auditor pria dan wanita dalam melakukan tugas audit. Berdasarkan uraian dan hasil penelitian sebelumnya maka maka hipotesis dalam penelitian ini adalah sebagai berikut. $\mathrm{H}_{5}$ : Gender berpengaruh terhadap Kualitas Audit.

\section{METODE PENELITIAN}

Penelitian ini dilakukan pada Kantor Akuntan Publik (KAP) di Bali yang terdaftar dalam Direktori yang diterbitkan oleh Institut Akuntan Publik Indonesia (IAPI) tahun 2019 yang diperoleh melalui situs www.iapi.or.id. Populasi dalam penelitian ini adalah seluruh auditor yang bekerja pada Kantor Akuntan Publik (KAP) di Bali yang merupakan anggota Institut Akuntan Publik Indonesia (IAPI) tahun 2019. Pada penelitian ini populasi berjumlah 78 auditor. Model persamaan regresi yang digunakan dalam penelitian ini diasumsikan linear dan diuji dengan tingkat signifikansi $a=0,05$. Model regresi linear berganda dirumuskan sebagai berikut.

$Y=\alpha+\beta 1 X 1+\beta 2 X 2+\beta 3 X 3+\beta 4 X 4+\beta 5 X 5+$ e.

Keterangan:

$$
\begin{array}{ll}
\mathrm{Y} & =\text { Kualitas Audit } \\
\mathrm{a} & =\text { Konstan } \\
\beta_{1} \ldots \beta_{5} & =\text { Koefisien regresi } \\
\mathrm{X}_{1} & =\text { Independensi } \\
\mathrm{X}_{2} & =\text { Profesionalisme } \\
\mathrm{X}_{3} & =\text { Skeptisme Profesional } \\
\mathrm{X}_{4} & =\text { Etika Profesi } \\
\mathrm{X}_{5} & =\text { Gender } \\
\mathrm{e} & =\text { error }
\end{array}
$$

\section{HASIL DAN PEMBAHASAN}

Perhitungan koefisien regresi linier berganda dilakukan dengan analisis regresi melalui software SPSS 18.0 for Windows, diperoleh hasil yang ditunjukan pada Tabel 1.

\section{Tabel 1. Hasil Analisis Regresi Linier Berganda}

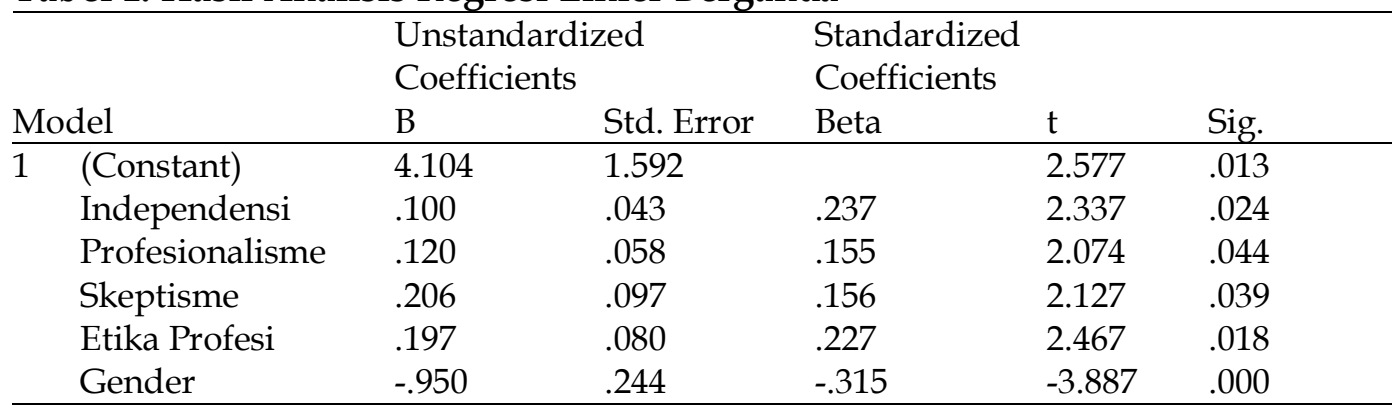

Sumber: Data Penelitian, 2019

Berdasarkan Tabel 1. dapat dibuat suatu model persamaan regresi linear berganda yaitu sebagai berikut:

$$
Y=4,104+0,100 X_{1}+0,120 X_{2}+0,206 X_{3}+0,197 X_{4}+-0,950 X_{5}
$$


Nilai konstanta (a) sebesar 4,104 memiliki arti jika variabel independensi (X1), profesionalisme (X2), Skeptisme Profesional (X3), Etika Profesi (X4) dan gender (X5) dinyatakan konstan pada angka 0 , maka nilai kualitas audit (Y) sebesar 4,104 berarah positif. Nilai koefisien $\beta_{1}$ pada variabel independensi sebesar 0,100 dengan arah koefisien regresi yang bernilai positif. Hal ini menunjukkan apabila nilai independensi meningkat sebesar satu satuan maka kualitas audit $(\mathrm{Y})$ akan meningkat sebesar 0,100 dengan asumsi variabel lain konstan. Nilai koefisien $\beta_{2}$ pada variabel profesionalisme sebesar 0,120 dengan arah koefisien regresi yang bernilai positif. Hal ini menunjukkan apabila nilai profesionalisme meningkat sebesar satu satuan maka kualitas audit (Y) akan meningkat sebesar 0,120 dengan asumsi variabel lain konstan. Nilai koefisien $\beta_{3}$ pada variabel skeptisme profesional sebesar 0,206 dengan arah koefisien regresi yang bernilai positif. Hal ini menunjukkan apabila nilai skeptisme profesional meningkat sebesar satu satuan maka kualitas audit (Y) akan meningkat sebesar 0,206 dengan asumsi variabel lain konstan. Nilai koefisien $\beta_{4}$ pada variabel etika profesi sebesar 0,197 dengan arah koefisien regresi yang bernilai positif. Hal ini menunjukkan apabila nilai etika profesi meningkat sebesar satu satuan maka kualitas audit (Y) akan meningkat sebesar 0,197 dengan asumsi variabel lain konstan. Nilai koefisien $\beta_{5}$ pada variabel gender sebesar $-0,950$ dengan arah koefisien regresi yang bernilai negatif. Hal ini menunjukkan setiap kenaikan gender sebesar satu satuan maka kualitas audit $(\mathrm{Y})$ akan menurun sebesar -0,95 dengan asumsi variabel lain konstan.

Analisis koefisien determinasi dilakukan untuk mengukur seberapa besar variabel bebas mampu menjelaskan perubahan variabel terikatnya. Pada penelitian ini koefisien determinasi dilihat dari nilai Rsquare yang terlihat pada Tabel 2.

Tabel 2. Hasil Uji Koefisien Determinasi

\begin{tabular}{ccccc}
\hline Model & $\mathrm{R}$ & R Square & $\begin{array}{c}\text { Adjusted R } \\
\text { Square }\end{array}$ & Std. Error of the Estimate \\
\hline 1 & $.943^{\mathrm{a}}$ & .890 & .877 & .51256 \\
\hline
\end{tabular}

Sumber: Data Penelitian, 2019

Berdasarkan Tabel 2. dapat dilihat bahwa nilai Rsquare pada model sebesar 0,890 atau 89 persen, ini artinya sebesar 89 persen variasi kualitas audit dipengaruhi oleh independensi $\left(X_{1}\right)$, profesionalisme $\left(X_{2}\right)$, skeptisme profesional $\left(X_{3}\right)$, etika profesi $\left(X_{4}\right)$, gender $\left(X_{5}\right)$ sedangkan sisasnya 11 persen dijelaskan oleh faktor lain yang tidak dijelaskan pada penelitian ini.

Uji kelayakan model (uji F) bertujuan untuk menguji apakah semua variabel bebas berpengaruh terhadap variabel terikat dan untuk mengetahui model regresi yang digunakan dalam penelitian ini layak diuji atau tidak.

Tabel 3. Hasil Uji Kelayakan Model (Uji F)

\begin{tabular}{lllllll}
\hline Model & & Sum of Squares df & Mean Square & F & Sig. \\
\hline 1 & Regression & 93.260 & 5 & 18.652 & 70.996 & $.000^{\mathrm{b}}$ \\
& Residual & 11.560 & 44 & .263 & & \\
& Total & 104.820 & 49 & & & \\
\hline
\end{tabular}

Sumber: Data Penelitian, 2019

Berdasarkan Tabel 3. hasil perhitungan regresi linier berganda menunjukkan bahwa sig.F $=0,000$ lebih kecil dari 0,05 sehingga dapat 
disimpulkan bahwa penelitian ini layak untuk digunakan sebagai alat analisis untuk menguji pengaruh variabel independen terhadap variabel dependen.

Pada tabel 1 dapat dilihat bahwa nilai tingkat signifikansi uji $\mathrm{t}$ untuk variabel independensi sebesar 0,024 sehingga $\mathrm{H}_{1}$ diterima, maka tingkat signifikan $\mathrm{t}$ adalah $0,024<0,05$. Hal ini mengindikasikan bahwa independensi berpengaruh positif dan signifikan pada kualitas audit.

Pada tabel 1 dapat dilihat bahwa nilai tingkat signifikansi uji $\mathrm{t}$ untuk variabel independensi sebesar 0,044 sehingga $\mathrm{H}_{2}$ diterima, maka tingkat signifikan $\mathrm{t}$ adalah $0,044<0,05$. Hal ini mengindikasikan bahwa profesionalisme berpengaruh positif dan signifikan pada kualitas audit.

Pada tabel 1 dapat dilihat bahwa nilai tingkat signifikansi uji $t$ untuk variabel skeptisme profesional sebesar 0,039 sehingga $\mathrm{H}_{3}$ diterima, maka tingkat signifikan $\mathrm{t}$ adalah $0,039<0,05$. Hal ini mengindikasikan bahwa skeptisme profesional berpengaruh positif dan signifikan pada kualitas audit.

Pada tabel 1 dapat dilihat bahwa nilai tingkat signifikansi uji $\mathrm{t}$ untuk variabel etika profesi sebesar 0,018 sehingga $\mathrm{H}_{4}$ diterima, maka tingkat signifikan $\mathrm{t}$ adalah $0,018<0,05$. Hal ini mengindikasikan bahwa etika profesi berpengaruh positif dan signifikan pada kualitas audit.

Pada tabel 1 dapat dilihat bahwa nilai tingkat signifikansi uji $\mathrm{t}$ untuk variabel gender sebesar 0,000 sehingga $\mathrm{H}_{5}$ diterima, maka tingkat signifikan $\mathrm{t}$ adalah 0,000 < 0,05. Hal ini mengindikasikan bahwa gender berpengaruh negatif signifikan pada kualitas audit.

Hasil penelitian menunjukkan bahwa $\beta_{1}=0,100$ dengan tingkat signifikan sebesar 0,024 yang lebih kecil dari taraf nyata dalam penelitian ini, yaitu 0,05 artinya independensi berpengaruh positif dan signifikan pada kualitas audit, maka hipotesis pertama $\left(\mathrm{H}_{1}\right)$ diterima. Hal ini berarti bahwa semakin tinggi tingkat independensi yang dimiliki seorang auditor maka semakin tinggi pula kualitas audit yang dihasilkan. Sikap independensi adalah sikap tidak memihak yang ditunjukkan auditor ketika melaksanakan tugasnya mencerminkan auditor bebas dari pengaruh apapun dan bersikap jujur tidak hanya kepada manajemen dan pemilik perusahaan, tetapi juga kepada kreditor dan pihak lain yang menaruh kepercayaan atas laporan keuangan auditan. Penelitian ini sejalan dengan penelitian yang dilakukan oleh Octaviana, (2013), Laksita \& Sukirno, (2019) dan Rahmina \& Agoes, (2014) memiliki hasil penelitian yang sama yaitu independensi berpengaruh positif pada kualitas audit.

Hasil penelitian menunjukkan bahwa $\beta_{2}=0,120$ dengan tingkat signifikan sebesar 0,044 yang menunjukkan angka lebih kecil dari taraf nyata penelitian yaitu 0,05 artinya profesionalisme berpengaruh positif dan signifikan pada kualitas audit, maka hipotesis kedua $\left(\mathrm{H}_{2}\right)$ diterima. Profesionalisme merupakan komponen kualitas yang benar-benar harus dipertahankan oleh akuntan publik. Kualitas audit disini berarti akuntan publik lebih mengutamakan kepentingan publik di atas kepentingan manajemen atau kepentingan auditor itu sendiri dalam membuat laporan auditan (IAPI, 2013).

Hal ini berarti bahwa semakin tinggi sikap profesionalisme yang dimiliki auditor maka akan meningkatkan kualitas audit. Hasil ini selaras dengan penelitian yang dilakukan oleh Pradipta \& Budiartha, (2016), Dewi \& Ramantha, (2019) yang menyatakan bahwa profesionalisme memiliki hubungan yang positif 
dan signifikan terhadap kualitas audit. Hal ini menunjukkan bahwa semakin tinggi profesionalisme yang dimiliki auditor maka akan meningkatkan kualitas audit.

Hasil penelitian menunjukkan bahwa $\beta_{3}=0,206$ dengan tingkat signifikan sebesar 0,039 yang menunjukkan angka lebih kecil dari taraf nyata penelitian yaitu 0,05 artinya skeptisme profesional berpengaruh positif dan signifikan pada kualitas audit, maka hipotesis ketiga $\left(\mathrm{H}_{3}\right)$ diterima. Hal ini berarti bahwa semakin tinggi skeptisme profesional yang dimiliki auditor maka akan meningkatkan kualitas audit. Ketidakmampuan auditor dalam mendeteksi kecurangan dan kekeliruan laporan keuangan merupakan cerminan dari rendahnya skeptisme profesional yang dimiliki auditor. Skeptisme profesional adalah sikap yang selalu mempertanyakan dan melakukan evaluasi bukti audit secara kritis. Skeptisme profesional adalah sikap yang meliputiu pikiran yang selalu bertanya-tanya dan waspada terhadap kondisi dan keadaan yang mengindikasikan adanya kemungkinan salah saji material yang disebabkan oleh kesalahan atau kesengajaan dan penilaan bukti-bukti audit secara kritis. Hasil ini selaras dengan penelitian yang dilakukan oleh Triarini \& Latrini, (2016), Merici, et al., (2014) yang menyatakan bahwa skeptisme profesional auditor sangat dibutuhkan auditor dalam menentukan kualitas laporan audit yang dihasilkan. Dengan memiliki sikap skeptik yang tinggi maka auditor dapat mencari dan menemukan bukti pemeriksaan yang kompeten, sehingga dengan bukti pemeriksaan yang berkompeten tersebtu dapat meningkatkan kualitas audit. Auditor dapat mengikuti pelatihan dan pembinaan secara berkesinambungan atau mengikuti pendidikan dan pelatihan (diklat), sehingga dapat menambah pengetahuan serta pengalaman auditor. Dengan bertambahnya pengetahuan dan pengalama auditor, diharapkan dapat mempertahankan dan meningkatkan skeptisme profesional auditor. Sehingga dengan meningkatnya skeptisme profesional dapat meningkatkan kualitas audit.

Hasil penelitian menunjukkan bahwa $\beta_{4}=0,197$ dengan tingkat signifikan sebesar 0,018 yang menunjukkan angka lebih kecil dari taraf nyata penelitian yaitu 0,05 artinya etika profesi berpengaruh positif dan signifikan pada kualitas audit, maka hipotesis keempat $\left(\mathrm{H}_{4}\right)$ diterima. Teori atribusi dapat menjelaskan bahwa timbulnya ketidakkonsistenan pada diri auditor untuk mengikuti atau tidak mengikuti sebagian dari kode etik, serta perbedaan persepsi individu mengenai hal yang etis atau tidak etis dapat menimbulkan ketidakselarasan. Pelaksanaan pekerjaan profesional tidak lepas dari etika karena perilaku profesional diperlukan bagi semua profesi agar profesi yang dijalaninya mendapat kepercayaan dari masyarakat. Etika sebagai suatu aturan atau standar yang menentukan tingkah laku para anggota dari suatu profesi. Dengan kesadaran etis yang tinggi, maka seorang auditor cenderung profesional dalam tugasnya dan menjalankan tugasnya sesuai dengan kode etik profesi dan standar auditing. Hal ini berarti bahwa semakin auditor menjunjung tinggi etika profesi maka akan menghasilkan kualitas audit yang semakin baik dan mempengaruhi kepercayaan masyarakat terhadap profesi auditor. Etika profesi merupakan landasan etika yang harus dipahami dan dilaksanakan oleh setiap auditor. Dalam melaksanakan pemeriksaan, seorang auditor harus menjujung tinggi etika profesinya sebagai auditor agar tercipta transparasi dalam pengelolaan 
keuangan. Hasil ini selaras dengan penelitian yang dilakukan oleh Kurnia, et al., (2014), Prasetyo \& Utama, (2015) yang menyatakan bahwa etika profesi memiliki hubungan yang positif dan signifikan terhadap kualitas audit.

Hasil penelitian menunjukkan bahwa $\beta_{5}=-0,950$ dengan tingkat signifikan sebesar 0.000 yang menunjukkan angka lebih kecil dari taraf nyata penelitian yaitu 0.05 artinya gender berpengaruh negatif dan signifikan pada kualitas audit, maka hipotesis kelima $\left(\mathrm{H}_{5}\right)$ diterima. Hal ini berarti bahwa perbedaan gender antara laki-laki dan perempuan dengan perbedaan karakter dan sifat yang melekat pada individu masing-masing tidak berpengaruh pada kualitas audit yang dihasilkan. Hal ini dikarenakan laki-laki dan perempuan memiliki peluang yang sama dalam melaksanakan tanggungjawab dan prestasinya sebagai seorang auditor. Gender yang dimiliki seorang auditor tidak dapat mempengaruhi sikap maupun kemampuan auditor dalam melaksanakan tugas pengauditan. Hasil ini selaras dengan penelitian yang dilakukan oleh Ningsih, et al., (2015), Widiarta, (2013), dan Salsabila \& Prayudiawan, (2011) bahwa gender berpengaruh negatif dan signifikan pada kualitas audit.

\section{SIMPULAN}

Hasil penelitian ini berhasil mendukung hipotesis pertama bahwa independensi berpengaruh positif dan signifikan pada kualitas audit. Hal ini menunjukkan bahwa semakin tinggi tingkat independensi yang dimiliki seorang auditor, maka semakin tinggi pula kualitas audit yang dihasilkan auditor karena auditor tidak akan mudah terpengaruh oleh apapun dalam melaksanakan audit. Hasil penelitian ini berhasil mendukung hipotesis kedua bahwa profesionalisme berpengaruh positif dan signifikan pada kualitas audit. Hal ini menunjukkan bahwa semakin tinggi tingkat profesionalisme yang dimiliki seorang auditor, maka semakin tinggi pula kualitas audit yang dihasilkan auditor tersebut. Hasil penelitian ini berhasil mendukung hipotesis ketiga bahwa skeptisme profesional berpengaruh positif dan signifikan pada kualitas audit. Hal ini menunjukkan bahwa semakin tinggi sikap skeptisme profesional yang dimiliki oleh auditor, maka semakin baik kualitas audit yang dihasilkan auditor tersebut. Hasil penelitian ini berhasil mendukung hipotesis keempat bahwa etika profesi berpengaruh positif dan signifikan pada kualitas audit. Hal ini menunjukkan bahwa semakin auditor menjunjung tinggi etika profesi maka semakin baik kualitas audit yang dihasilkan auditor tersebut. Hasil penelitian ini berhasil mendukung hipotesis kelima bahwa gender berpengaruh pada kualitas audit. Hal ini menunjukkan bahwa auditor laki-laki dan perempuan memiliki kemampuan, independensi, komitmen dan tanggungjawab yang sama dalam memberikan jasa audit yang berkualitas.

Berdasarkan nilai R Square dalam penelitian ini $89 \%$ peneliti menyarankan untuk menguji variabel kualitas audit dengan menambah variabel independensi seperti pengalaman, pendidikan dan spesialisasi auditor. Penelitian selanjutnya diharapkan menggunakan metode wawancara atau observasi langsung kepada responden agar dapat memperkuat hasil penelitian. Penelitian selanjutnya disarankan dapat menambah jumlah sampel dengan memperluas wilayah penelitian hingga luar Bali sehingga hasil penelitian nantinya akan dapat digeneralisasikan karena pada saat tertentu tidak semua KAP bersedia mengisi 
kuesioner penelitian dikarenakan kesibukan auditor dalam melakukan pengauditan. Bagi Kantor Akuntan Publik (KAP) agar dapat meningkatkan dan mempertahankan etika profesi bagi auditornya agar tidak terjadinya manipulasi laporan keuangan dikemudian hari dan meningkatkan sikap tersebut agar menghasilkan kinerja yang maksimal.

\section{REFERENSI}

Adrian, A. (2013). Pengaruh skeptisme profesional, etika, pengalaman, dan keahlian audit terhadap ketepatan pemberian opini oleh auditor. Jurnal Akuntansi, 1(3), 90-121.

Arumsari, A. L., \& Budiartha, I. K. (2016). Pengaruh Profesionalisme Auditor, Independensi Auditor, Etika Profesi, Budaya Organisasi, dan Gaya Kepemimpinan terhadap Kinerja Auditor pada Kantor Akuntan Publik di Bali. E-Jurnal Ekonomi Dan Bisnis Universitas Udayana, 5(8), 2297-2304.

Carpenter, T., Gaynor, L. M., \& Duetschi, C. (2002). The Role of Experience in Professional Skepticism, Knowledge Acquisition, and Fraud Detection. Americal Accounting Association, 1-28. Retrieved from https:/ / scholar.google.co.id/scholar?hl=id\&as_sdt=0\%2C5\&as_vis $=1 \&$ $\mathrm{q}=.+$ The + role + of + experience $+\mathrm{in}+$ professional+skepticism $\% 2 \mathrm{C}+$ knowle dge+acquisition $\% 2 \mathrm{C}+$ and +fraud+detection.+Retrieved\&btnG=

Darley, W. K., \& Smith, R. E. (1995). Gender differences in information processing strategies: An empirical test of the selectivity model in advertising response. Journal of Advertising, 24(1), 41-56. https:// doi.org/10.1080/00913367.1995.10673467

Dewi, A. A. C., \& Ramantha, I. W. (2019). Pengaruh Profesionalisme dan Time Budget Pressure pada Kualitas Audit dengan Fee Audit sebagai Variabel Pemoderasi. E-Jurnal Akuntansi Universitas Udayana, 26(1), 563-590. Retrieved from http://www.tjyybjb.ac.cn/CN/article/downloadArticleFile.do?attachT ype $=$ PDF\&id $=9987$

Elder, et al. (2011). Jasa Audit dan Assurance : Pendekatan Terpadu. Jakarta: Salemba Empat.

Futri, P. S., \& Juliarsa, G. (2014). Pengaruh Independensi, Profesionalisme, Tingkat Pendidikan, Etika Profesi, Pengalaman dan Kepuasan Kerja Auditor pada Kualitas Audit Kantor Akuntan Publik di Bali. E- Jurnal Akuntansi Universitas Udayana, 7(2), 444-461. https:// doi.org/10.1111/j.1365-2761.1986.tb01041.x

Haryanto, N. O., \& Susilawati, C. (2018). Pengaruh Kompetensi, Independensi, dan Profesionalisme Auditor Internal Terhadap Kualitas Audit. Jurnal Akuntansi Bisnis, 16(2), 42-55. https://doi.org/10.24167/jab.v16i2.1694

Herawaty, A., \& Susanto, K. (2009). Pengaruh Profesionalisme, Pengetahuan Mendeteksi Kekeliruan, dan Etika Profesi Terhadap Pertimbangan Tingkat Materialitas Akuntan Publik. Jurnal Akuntansi Dan Keuangan, 11(1), 13-20. https:// doi.org/10.9744/jak.11.1.pp.13-20

Herliansyah, Y., \& Ilyas, M. (2006). Pengaruh Pengalaman Auditor terhadap Penggunaan Bukti Tidak Relevan dalam Auditor Judgment. Simposium Nasional Akuntansi 9 Padang, 9, 23-26. 
IAPI. (2013). Standar Profesional Akuntan Publik. Jakarta. Retrieved from iapi.or.id/iapi/detail/362

Indayani, P. I., Sujana, E., \& Sulindawati, N. L. G. E. (2015). Pengaruh gender, tingkat pendidikan formal, pengalaman kerja auditor terhadap kualitas audit ( Studi Empiris Pada Kantor Inspektorat Kota Denpasar , Kabupaten Badung dan Kabupaten Buleleng ). E-Journal Universitas Pendidikan Ganesha, 3(1).

Kurnia, W., Khomsiyah, K., \& Sofie, S. (2014). Pengaruh Kompetensi, Independensi, Tekanan Waktu, Dan Etika Auditor Terhadap Kualitas $\begin{array}{lllll}\text { Audit. Jurnal Akuntansi } & 49 .\end{array}$ https:// doi.org/10.25105/jat.v1i2.4826

Laksita, A. D., \& Sukirno. (2019). Pengaruh Independensi, Akuntabilitas, Dan Objektivitas Terhadap Kualitas Audit. Jurnal Nominal, 8(1), 31-46. https:// doi.org/10.21831/nominal.v8i1.24497

Lesmana, R., \& Machdar, N. M. (2015). Pengaruh Profesionalisme , Kompetensi , dan Independensi Auditor terhadap Kualitas Audit. Jurnal Bisnis Dan Komunikasi, 2(1), 33-40.

Maulana, Y. (2019). Pengaruh Pengalaman Auditor, Etika Auditor dan Gender terhadap Kualitas Audit. Jurnal Ilmiah Indonesia, 4(2), 75-84. https:// doi.org/.1037//0033-2909.I26.1.78

Merici, C. A., Halim, A., \& Wulandari, R. (2014). Pengaruh Skeptisisme Profesional, Pengalaman Audit, Keahlian Audit, Independensi, Dan Kompetensi Terhadap Ketepatan Pemberian Opini Auditor Pada Kap Kota Malang. Jurnal Riset Mahasiswa Akuntansi, 1-13.

Ningsih, S., Prita, S., \& Sofianti, D. (2015). Pengaruh Kompetensi , Independensi dan Jenis Kelamin Auditor Terhadap Kualitas Audit dengan Kecerdasan Emosional Sebagai Variabel Moderasi: Studi Empiris pada Kantor Akuntan Publik di Malang ( The Effect Of Competence, Independence and Auditor' s Sex T. Artikel Ilmiah Mahasiswa.

Octaviana, A. (2013). Pengaruh Kompetensi, Independensi, Time Budget Pressure, Dan Audit Fee Terhadap Kualitas Audit Pada. Jurnal Ekonomi Dan Bisnis, (3), 266-278.

Pradipta, G., \& Budiartha, I. (2016). Tekanan Anggaran Waktu Sebagai Pemoderasi Pengaruh Profesionalisme Dan Pengalaman Audit Pada Kualitas Audit. E-Jurnal Akuntansi Universitas Udayana, 15(3), 1740-1766.

Prasetyo, E. B., \& Utama, I. M. K. (2015). Pengaruh Independensi, Etika Profesi, Pengalaman Kerja dan Tingkat Pendidikan Auditor pada Kualitas Audit. E-Jurnal Akuntansi Universitas Udayana, 11(1), 115-129.

Rahmina, L. Y., \& Agoes, S. (2014). Influence of Auditor Independence, Audit Tenure, and Audit Fee on Audit Quality of Members of Capital Market Accountant Forum in Indonesia. Procedia - Social and Behavioral Sciences, 164(August), 324-331. https:// doi.org/10.1016/j.sbspro.2014.11.083

Rai, I. G. A. (2008). Audit Kinerja pada Sektor Publik: Konsep, Praktik, Studi Kasus. Jakarta: Salemba Empat.

Salsabila, A., \& Prayudiawan, H. (2011). Pengaruh Akuntabilitas, Pengetahuan Audit, dan Gender terhadap Kualitas Hasil Kerja Auditor Internal. Jurnal Telaah \& Riset Akuntansi, 4(1), 155-175. 
Sugiarmini, N. L. A., \& Datrina, L. K. (2017). Pengaruh Skeptisme Profesional , Independensi, Kompetensi, Etika, Dan Role Stress Auditor Terhadap Kualitas Audit Pada Kantor BPK RI Perwakilan Provinsi Bali. Jurna Krisna (Kumpulan Riset Akuntansi), 9(1), 1-14. https:/ / doi.org/10.22225.KR.9.1.324.1-14

Triarini, D., \& Latrini, M. (2016). Pengaruh Kompetensi, Skeptisme Profesional, Motivasi, Dan Disiplin Terhadap Kualitas Audit Kantor Inspektorat Kabupaten/Kota Di Bali. E-Jurnal Akuntansi Universitas Udayana, 14(2), 1092-1119.

Waluyo, A. (2001). Skeptisme Profesional Auditor, 18-45. Retrieved from https://journal.ubm.ac.id/index.php/akuntansibisnis/article/download/256/249

Wardhani, A. A. I. T. W., \& Astika, I. B. P. (2018). Pengaruh Kompetensi, Akuntabilitas dan Independensi pada Kualitas Audit dengan Etika Auditor sebagai Variabel Moderasi. E-Jurnal Akuntansi Universitas Udayana, 23(1), 31-59. https:// doi.org/10.1271/nogeikagaku1924.12.328

Widiarta, W. (2013). Pengaruh Gender, Umur Dan Kompleksitas Tugas Auditor Pada Kualitas Audit Kantor Akuntan Publik Di Bali. E-Jurnal Akuntansi Universitas Udayana, 3(1), 109-118.

Yustrianthe, R. H. (2012). Beberapa Faktor Yang Mempengaruhi Audit Judgment Auditor Pemerintah. Jurnal Dinamika Akuntansi, 4(2), 72-82. https://doi.org/10.15294/jda.v4i2.2165 